International Review of Social History 43 (1998), pp. 45I-47I

(C) 1998 Internationaal Instituut voor Sociale Geschiedenis

\title{
Conscription and Popular Resistance in Iran, I925-I94I
}

\author{
STEPHANiE CRONIN
}

For the nationalist regimes of the inter-war Middle East, Riza Shah's Iran, Mustafa Kemal's Turkey and Hashemite Iraq, the construction of a strong national army based on universal military service was an essential element of state-building and nation-formation. Yet although conscription was ardently advocated by the nationalist intelligentsia, wherever it was actually imposed it aroused intense resentment. Nonetheless, although enforced conscription was almost universally unpopular, mass, collective and organized resistance was comparatively rare. In Iran such resistance occurred in three waves in the late 1920s. Uniquely in the Middle East, opposition in Iran was most sustained not in the rural areas but in the towns, in Isfahan and Shiraz in 1927 and in Tabriz in 1928, where it was led by the guilds and the ulama, although violent opposition was also manifested by the tribes in 1929. Riza Shah was irrevocably committed to conscription, which was a central pillar of his programme of modernization and secularization, and although prepared to temporize, was ultimately determined to crush collective resistance. By 1930 he had largely succeeded in so doing. The subsequent implementation of the policy was aided by a deliberate decision to defuse popular anger by tolerating, even encouraging, individual strategies of avoidance, in particular by allowing the manipulation of the exemptions system through bribery. As the 1930s progressed, conscription became established as an indelible feature of the new Iran.

\section{THE BUNICHAH SYSTEM}

In Iran modern conscription was first systematically enforced by Riza Shah in the second half of the rig2os, yet the measure itself, and its centrality to programmes of defensive modernization, has a much older pedigree. The first attempt to impose conscription was made in the early nineteenth century by the crown prince, Abbas Mirza. Directly inspired by the Ottoman example, Abbas Mirza devised a rudimentary scheme, known as the bunichah system, which he introduced in Azarbayjan as part of his attempts to construct a modern standing army with which to confront the Russian advance southwards.

The bunichah system was taken up by Amir-i Kabir, the reforming prime minister of the new shah, Nasir al-Din, and incorporated into his efforts to create a standing army as part of an overall reform of the state and government between 1848 and I85I. Although, like Abbas Mirza's experiment, Amir-i Kabir's wider programme also ended in frustration, nonetheless he 
did preside over the introduction of the first generalized and country-wide, albeit still rather primitive, system of conscription in Iran, a system which was to endure down to 1925 .

Under Amir-i Kabir the bunichah system was developed into a relatively complex measure. In the absence of more general administrative reforms, most importantly a census, responsibility for furnishing recruits was fixed collectively on the village, not on the individual. Liability for military service was tied to revenue assessments in the countryside. The method of calculation was to carry out a survey of the number of ploughs required to keep an area under cultivation, and to reckon on one man per plough as available for military service. ${ }^{2}$

From the early I850s, then, an approximation of a modern, standing army based on a form of conscription existed in Iran. However, these nizam regiments were, from a military point of view, almost completely useless. In practice the shah and his government still relied, as they had relied before any reform had been carried out, on irregular cavalry drawn from the tribes. These tribal levies, the men serving under their own chiefs and called into the field only for specific campaigns, constituted the only fighting force of any real effectiveness possessed by Iran throughout the nineteenth century and continued to be an important element of the army's fighting strength well into the twentieth century. ${ }^{3}$

The nizam in Iran played no role comparable to that of the reformed army in the Ottoman Empire. It was marginal to the political and military history of the period which included the constitutional revolution, the Great War and the coup of 192I, and was not able to comprise a nucleus for the revitalized army of the I920s. These roles fell rather to the two semi-modern forces created independently of the nizam, the Cossack Brigade/Division and the Government Gendarmerie, both of which depended largely for their rank and file on voluntary recruiting from the tribes. ${ }^{4}$

\section{THE REFORMS OF RIZA PAHLAVI}

In 192I Colonel Riza Khan, using the Iranian Cossack Division, carried out a coup which inaugurated a new period in both the general political history

I. For nineteenth-century attempts at military reform, see Stephanie Cronin, The Army and the Creation of the Pablavi State in Iran, I9I0-I926 (London and New York, 1997), pp. I-7.

2. The term bunichah is derived from the word bunah, in this context meaning an agricultural unit: A. Reza Sheikholeslami, The Structure of Central Authority in Qajar Iran (Atlanta, GA, 1997), p. 179 .

3. Cronin, The Army, pp. 5-6, I20-I25.

4. Ibid., pp. 27-29, 56-57. For the Government Gendarmerie see also Lt.-Col. Parviz Afsar, Tarikh-i Zhandarmiri-yi Iran (Qum, I332); Jahangir Qa'im Maqami, Tarikh-i Zhandarmiri-yi Iran (Tehran, 1355). For the Cossack Brigade/Division see Ahmad Amirahmadi, Khatirat-i Nakhustin Sipabbud-i Iran (Tehran, 1373); Amanallah Jahanbani, Khatirat-i az Dawran-i Darakhshan-i Riza Shah-i Kabir (Tehran, I346); F. Kazemzadeh, "The Origin and Early Development of the Persian 
of Iran and also, specifically, in its military development. First as war minister, then from 1923 as prime minister also, and from 1926 as shah, Riza Pahlavi embarked on the project of building a modern, centralized state, anchored in the ideology of secular nationalism, at the heart of which would be a modern army. ${ }^{\text {s }}$

Immediately after Riza Khan's coup, what remained of the nizam was incorporated into the Gendarmerie, which was then itself merged with the Cossack Division. ${ }^{6}$ These were to be the foundations of the new army. Plans were laid for rapid military expansion, including intensive enlistment, although no new recruiting policy was yet in place. In fact in the early I920s the army continued its reliance on the bunichah system, supplemented by voluntary enlistment and the permanent incorporation of small tribal contingents. However, the bulk of the actual fighting of the many campaigns of these years was still being carried out not by the regular troops but by the irregular tribal levies, raised and disbanded as occasion required.

The defects of the bunichah system had been generally recognized since the nineteenth century. A disadvantage of particular and increasing seriousness for a modern army was that it was imposed only on the agricultural districts, which could ill afford to spare labour, and did not apply to the towns, where there was a pool of underemployed manpower, and where skilled and better educated labour might be found for the technical services. Furthermore, although theoretically applicable to the whole country, with certain exceptions, the system was in fact only very partially enforced, imposed on parts of the country which had been traditional recruiting grounds, mainly Azarbayjan, and leaving other districts, notably the south, entirely exempt. The legal exceptions were significant and numerous: the inhabitants of towns where the land tax was not levied; sayyids (descendants of the Prophet); the ulama; peasant cultivators of the Crown lands; and all non-Muslims, Christians, Jews and Zoroastrians. Another serious problem was that no new revenue assessment had been made since the original survey of the early i85os. Fluctuations in population meant that quotas were out of date and anomalous. When a recruit was taken the length of service was for life, unless the soldier could buy a discharge from his superior, and the bunichah system was inevitably intensely unpopular with the peasantry, which led to the recruitment of "the village failures" and provided ample scope for bribery and corruption. ${ }^{7}$

In the early I920s the army made the first serious attempt to enforce the bunichah system throughout the country. However, the out of date quotas

Cossack Brigade", American Slavic and East European Review, I5, 3 (October 1956), pp. 35I-363. (NB. Persian language sources in these notes are cited using the Iranian shamsi calendar.)

5. Cronin, The Army.

6. Ibid.

7. Report on the Organization of the Persian Army, Lt.-Col. H.P. Picot, Durand to Salisbury, I8 January 1900, FO88I/7364. 
and the system's application to areas which, although theoretically liable, had customarily been absolved, led to turmoil in the countryside. In September 1923 it was reported from Kirman, hitherto always exempt, that forcible enlistment was causing panic in some villages and constituted a rich source of bribes to recruiting officers. ${ }^{8}$ Indeed the situation became so bad that by October the Officer Commanding Troops had halted recruiting due to the general uproar in the district over extortion by recruiting officers. Some villages had already been entirely deserted. A year later the situation in Kirman had not improved. According to the British consul both the army and military service had continued to grow in unpopularity, resulting in an increasing difficulty in obtaining recruits in the province. Landowners were being harried by the military authorities to provide recruits and were being obliged to pay their tenants larger and larger sums to induce them to enlist. On 2I August 1924 a group of these landowners threatened to take bast (sanctuary) in the British consulate in protest against the pressure that was being brought to bear on them by the army. ${ }^{9}$

During the years 1922-1926 numerical growth was slow and difficult and the provincial divisions remained considerably below their targeted strength of I0,000 men each. By the beginning of 1925 , the army still numbered less than 50,000. Riza Khan had quickly become exasperated with the antiquated recruiting methods employed by the army and between 1923 and I925 forced a conscription bill through the Majlis. He was supported in this by the nationalist intellectuals of the Revival and Socialist parties. For this trend, represented by the veteran constitutionalist, Hasan Taqizadah, the construction of an army based on conscription was an essential step in both the achievement and defence of national sovereignty and in the creation and inculcation of national identity. Religious opposition having been neutralized by a concession granting total exemption to all religious students, the conscription bill was passed by the Majlis in June $1925 .^{10}$

Although exemption had been granted to religious students, no concession was made to traditional Muslim sentiment regarding the application of conscription to the minorities of Iran: Christian, Jewish and Zoroastrian. When the deputy Sayyid Hasan Mudarris stated during the debate in the Majlis that, although bearing arms was a religious duty of the Muslim, non-Muslims were under no obligation and should not be compelled to serve in the army, the Zoroastrian Deputy, Arbab Kaykhusraw, made a spirited defence of his community's right and desire to share equally in the burdens as well as the privileges of citizenship. ${ }^{\text {II }}$ Although in practice there

8. Intelligence Summary (hereafter IS) no. 40, 6 October 1923, FO371/9020/EII740/69/34.

9. IS no. 40, 4 October 1924, $\mathrm{FO}_{37 \mathrm{I} / \mathrm{IOI} 32 \mathrm{E} 9746 / 255 / 34 .}$

Io. A translation of the bill as originally presented to the Majlis in April 1923 may be found in

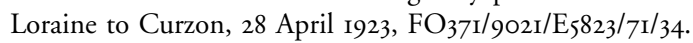

II. (American) Chargé d'Affaires, W. Smith Murray, to Secretary of State, Washington, 24 March 1925, National Archives Microfilm Publications, Microcopy 715, Roll I2. 
was already a significant Armenian presence in the army, in the form of an independently organized squadron with its own officers, the government's insistence on the general participation of the non-Muslim minorities and the public and official recognition of this participation represented a complete break with the past and symbolized the triumph of nationalism over religious and communal identity. However, the enthusiasm of sophisticated, politically conscious urban leaders was not altogether shared by their peasant constituencies. In January 1925, for example, the Christians of Urumiyah district were reported to be much disturbed by the government's intention to impose conscription on them and to have decided to emigrate if this were indeed the case. ${ }^{\mathrm{I}}$

Although containing references to the legitimacy of conscription in terms of Islamic law, the conscription act's ideological inspiration was clearly that of modern nationalism. In a preamble the act outlined the defects of the bunichah system and the benefits to be derived from a system of universal military service. It was stated that conscription would give the Iranian army a national character and would give all families in the country an interest in defending their nation and their independence. The army would be made strong enough to ward off any attack, taxation and recruitment would be fairer, ensuring enough persons remained to cultivate the land, and economies could be effected in the pay of the army. Point 7 of the preamble declared that conscription would result in an increase of patriotic sentiments among the Iranian people, mutual good feeling between various classes and the creation of feelings of equality while point 8 stressed the virtues of the avoidance of discrimination and the equality of all before the law.

The act imposed liability for military service on all males on reaching the age of 2I, with certain definite exceptions of which the most important were clerics and religious teachers, religious students and certain defined categories of men on whom others were dependent. The period of service was 25 years, divided into three categories: six years' active service, of which two were to be spent with the colours and the remainder in immediate reserve; thirteen years' reserve service; six years' service in the local guard (only to be called out in time of war). Reservists were to come up for training each year for varying periods. The men taken for service with the colours in any one year were to be chosen by the drawing of lots from among those liable for military service.

After the passage of the act through the Majlis, the government began to make various preparations for its implementation. The ministry of war could not begin to conscript recruits until the ministry of the interior had completed the national census, work on which had started earlier in 1925 . By the end of the year recruiting officers were being trained in their duties at Tehran, prior to being sent to the provinces where they were to assist the

I2. IS no. 9, 28 February 1925, $\mathrm{FO}_{37 \mathrm{I} / \mathrm{IO} 842 / \mathrm{E} 2098 / 82 / 34 .}$ 
officials of the interior ministry in taking the census and subsequently to begin enlisting conscripts. During early 1926 preparatory work for the enforcement of conscription progressed extremely slowly. It was not until the end of October that Riza Shah signed a decree ordering the application of the act from 7 November. Early in November notices were duly published warning all men in Tehran born in 1905 that they should present themselves to the recruiting commission on certain dates, according to the districts in which they lived, beginning with 7 November. The penalty for failing to appear was forcible enlistment and service for three years instead of two. Those entitled to exemption were requested to bring with them certificates from the relevant authorities.

The recruiting commission completed its work in Tehran towards the end of November but the results fell considerably short of expectations. Of the I,486 drawn by lot, I,I60 had failed to present themselves, while the remaining 326 were taken into service. The absentees had either absconded or had no existence, fictitious names having been entered on the census register by persons wishing to obtain extra voting cards for the Majlis elections. ${ }^{13}$

The ministry of war had begun to apply the conscription law in Tehran and its environs, where government control was more complete and the army more reliable, as it had immediately become apparent that considerable popular opposition to the measure existed throughout the country. In Kirman, for example, the announcement of the ratification of the law had been received with open apprehension while the initial work of the recruiting commission in Tehran in early November had produced hostile demonstrations. Rumours were gaining currency within the army itself that the ulama of the Shi'i shrine cities of Najaf and Karbala had pronounced against conscription and that the measure was British-inspired.

By the end of 1926 the imposition of conscription was still limited almost entirely to the capital and its environs, the provinces of Tehran, Qazvin and Hamadan, and even there had yielded disappointing results. Exemptions were numerous and the number of men conscripted did not exceed 2-3,000. In early 1927 the government formulated the clear intention to apply the law more energetically throughout the country. Recruiting offices were established and calling up notices posted in all the provincial capitals. However, strong opposition immediately appeared. For example in January disturbances broke out in Sultanabad following the arrival of recruiting officers. The bazars were closed and the offices of the recruiting commission attacked. These disorders were only quelled by the arrival of more troops. ${ }^{14}$ Nonetheless the government pressed on, although it quickly became impos-

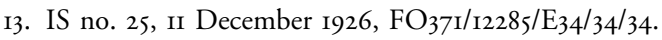

I4. IS no. I, 8 January 1927, $\mathrm{FO}_{37 \mathrm{I} / \mathrm{I} 2285 / \mathrm{E}_{512} / 34 / 34}$; IS no. 2, 22 January 1927, FO37I/I2285/ $\mathrm{E} 883 / 34 / 34$. 
sible for it to ignore the fact that recruitment was being accompanied by gross corruption. In May a joint commission, consisting of representatives of the ministries of war and the interior, left Tehran to tour the provinces to enquire into the complaints made regarding the methods used in the enforcement of conscription.

Although resentment at conscription had been intense, it had so far resulted only in sporadic and spontaneous defiance. However, the attempt to impose conscription on the towns of southern Iran in the autumn of I927 produced a dramatic, concerted and well-organized example of popular resistance. Prior to 192I the agriculturally-based bunichah system had customarily not been enforced in the south and the efforts of the army in the early I920s to take recruits from the peasantry in Fars and Kirman had been met with shock and hostility. The unprecedented imposition of conscription on the towns of the south was intolerable to the urban population and the labour guilds in particular were solidly opposed to the new law.

\section{ANTI-CONSCRIPTION PROTEST}

The anti-conscription movement in southern Iran was led by the ulama, who utilized to the full their traditional networks of support among the guilds and the merchants in the bazar. During the passage of the conscription bill through the Majlis clerical deputies had put up little opposition, yet the underlying concern of the ulama at the secularizing impact of military service was apparent. By 1927 conscription for the ulama had become enmeshed in a web of hostility to the central government and the shah. ${ }^{15}$ In his rise to power Riza had always retreated when faced with concerted religious opposition, most famously in his abandonment of republicanism in 1924, and had been careful to compromise at certain key moments. But in 1927-1928, following the stabilization of his newly founded dynasty, his regime introduced a raft of radical secularizing, centralizing reforms, and began their implementation in an aggressive manner. The ulama were aware that the balance of power between themselves and the regime was about to alter decisively to their detriment. Although on the defensive, they were bracing themselves for a struggle. They were particularly angry at the reorganization and secularization of Iran's judicial system which was pushed through during 1927 and which threatened their role, status and income, indeed deprived altogether large numbers of minor clerics of their livelihoods. Another momentous change heralding rapid and profound cultural secularization and enforced uniformity was inaugurated by the cabinet's decision in early August to make the "Pahlavi hat", similar to the French

15. See, for example, Shahrough Akhavi, Religion and Politics in Contemporary Iran: Clergy-State Relations in the Pahlavi Period (New York, 1980). 
kepi, the official headgear for Iranian men. ${ }^{16}$ The ulama had also been made anxious and fearful at the rise of Abd al-Husayn Taymurtash, the shah's new minister of court and a strong advocate of modernization, whom they believed had particularly influenced the shah against them. They had been especially provoked by the formation, in August 1927 by Taymurtash and other leading secularizers, of the New Iran party, from membership of which anyone not wearing the "Pahlavi hat" was expressly debarred, a provision aimed at the turban-wearing ulama. They also gave free expression to the cynicism and anger widely felt by the general population at the conduct of elections to the sixth Majlis, which had been rigged by the authorities.

The increasing friction between regime and ulama gave rise to a number of incidents during 1927. Between 16-25 April the bazars in Shiraz were closed, there were mass protest demonstrations with some rioting, and telegrams were sent to leading mujtahids and the Majlis, over the deportation by the military authorities of a minor mulla who had denounced the registration of women for the census. The military authorities were forced to yield and permit the return of the deported mulla. ${ }^{17}$ In late August the ulama of Isfahan led demonstrations of protest at the arrest of a preacher who had criticized the shah and the introduction of the Pahlavi hat. For eight days the Isfahan bazars were closed, and crowds assembled at the telegraph office to send telegrams to Tehran. The preacher was accordingly released and the ulama went on to demand successfully the dismissal of the chief of police. ${ }^{18}$ In October the ulama in Tehran, Isfahan and Mashhad launched a campaign against the New Iran party. Leading clerics in Tehran threatened to leave the city, those in Isfahan threatened to go into bast in Qum. Thereupon the shah, in any case exasperated by the squabbling to which the party had been prone, advised it to cease its activities.

As these skirmishes indicated, the ulama were still capable of achieving limited victories at the local level. However, their capacity to oppose the regime over a major issue was severely hampered by the general absence of any outstanding figure who could offer national leadership. In the capital itself, to which the provincial ulama increasingly looked, the few important mujtahids were highly vulnerable to pressure from the central government. The centre of gravity of the movement against conscription therefore shifted to southern Iran where opposition was fiercest.

Isfahan took the lead, followed by Shiraz and by towns elsewhere in Iran including Tehran, Mashhad and Qazvin, although the southern towns of Isfahan and Shiraz became and remained the centres of the anti-conscription movement. The protest began when the aged mujtahid Ayatullah Haj Agha 
Nurullah Isfahani, in response to a request from the people of Isfahan, agreed to go to the shrine city of Qum ${ }^{19}$ and from there lead a campaign against conscription. ${ }^{20}$ It was also hoped that the most important cleric resident in Qum, Shaykh Abd al-Karim Ha'iri, might be persuaded to take an active part in the campaign. ${ }^{21}$ Isfahani and several of his colleagues, including Ayatullah Mirza Husayn Fishariki, accordingly took up residence in Qum where they were joined by clerical representatives from Tehran and many provincial towns, including Shiraz, Hamadan, Mashhad and Tabriz, and from Najaf in Iraq. However, Isfahani failed to attract the support of the clerical representative in Qum, Ha'iri, who had a personal history of political non-involvement, openly declaring his neutrality. Isfahani was further weakened by the fact that the ulama who joined him in Qum were, with one or two exceptions, very minor figures.

The day designated for the first call-up of conscripts in Shiraz was 8 October. On that day the bazars in Shiraz closed down and remained closed as a protest against conscription, and trade came to a standstill. ${ }^{22}$ Similar action was taken in Isfahan and to a lesser extent in Kirmanshah, Qazvin and Tehran. The bazars in Isfahan and Shiraz, where opposition was most determined, were in fact to remain closed for three months. The occupational guilds were adamantly opposed to conscription and from 16 October organized in Shiraz and elsewhere a general strike, prevailing upon carpenters, masons, brickmakers and so on to stop work. In Tehran not only were the bazars closed but there were attempts by crowds to demonstrate in front of the Majlis although these were prevented by the police. Petitions were presented to the shah, but these were also of no avail as he gave the cynical reply that as the Majlis had introduced conscription he, as a constitutional monarch, was obliged to give effect to the law. ${ }^{23}$

The government at first responded to these developments with indifference, protests from the southern towns to the capital receiving only the reply that people could continue to keep their businesses closed if they wished providing there were no disorders. However, the local authorities, perceiving more clearly the depth of opposition and the gravity of the situation, were more active, launching a propaganda war and attempting to dissuade the protesters from further activity. In Shiraz the governor-general arranged for the Shiraz Majlis deputies to meet a delegation from the opposition on II October, on the grounds that it was the Majlis deputies who were responsible for the conscription law. However, the Majlis deputies

19. The shrine city of Qum, burial-place of Fatimah, the sister of the eighth Imam, was an important centre of Shi'i learning and possessed a tradition of offering bast to those in dispute with the temporal authority.

20. Husayn Makki, Tarikh-i Bist Salah-i Iran, 8 vols (Tehran, I323), vol. 4, pp. 4I5-439.

2I. Annual Report, 1927, Clive to Chamberlain, 21 May 1928, FO371/13069/E2897/2897/34.

22. Consul Chick, Shiraz, to Clive, 22 October 1927, FO37I/12293/E4979/520/34.

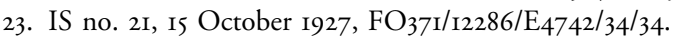


utterly failed to alter the opinions of the delegation, and were indeed rebuffed and humiliated by the encounter. The delegation bluntly denounced both the legitimacy of the Majlis and the regime's perversion of constitutional procedure. The Shirazis told their deputies that they were not genuine representatives of theirs but were nominees of the government and had been forced to comply; that there had been no Majlis properly elected by the people since the third; that according to the constitution five mujtahids must have a place in the Majlis and a voice in its proceedings; and that since other laws passed by the Majlis were flouted and ignored by the government, as far as they were concerned the conscription law could suffer the same fate. ${ }^{24}$

Although martial law was declared in Isfahan and troop reinforcements arrived, yet the authorities could make no impact on the solidity of the strikes there and at Shiraz and in Qum. However, in Tehran the agitation against conscription calmed down, though various anonymous leaflets, threatening terrorist action if the law were not modified, reached the shah. The government now showed clear signs of compromise and retreat. On 24 October the shah summoned groups of ulama, merchants and deputies and made to them a lengthy speech, the theme of which was his personal devotion to Islam. This heartened the ulama who regarded it as an admission that the shah was frightened of religious opinion. ${ }^{25}$ The government issued orders to the police and the military to deal leniently with anti-conscription demonstrators in Tehran and the shah also gave orders for leniency in the carrying out of conscription. On I2 November conscription ceased entirely in Tehran. Furthermore, although out of a total of 3,342 called up, I,III were taken, these were all given a certificate stating that, although they had been conscripted, they would not be called to the colours for the time being. ${ }^{26}$ In this way the government hoped to avoid aggravating the crisis while it decided upon a strategy.

Although the shah had been greatly angered by the protests, nonetheless his acute understanding of political reality and his ready appreciation of political danger indicated the necessity of a tactical retreat, coupled with the appearance of compromise. Early in November he sent his minister of court, Abd ul-Husayn Taymurtash, to Qum to meet the ulama, especially those who had taken refuge there from Isfahan. However, Taymurtash achieved little, the Isfahan ulama declining to see him. ${ }^{27}$ It was by now generally believed that the shah was prepared to compromise with the ulama over conscription. Hints were dropped that although there would be no actual annulment of the conscription law, its execution would be carried

24. Chick, Shiraz, to Clive, 22 October 1927

25. IS no. 22, 29 October $1927, \mathrm{FO}_{371} / \mathrm{I}_{2286 / \mathrm{E}_{4982} / 34 / 34}$.

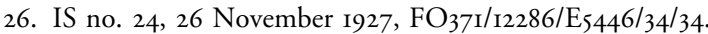

27. Clive to Chamberlain, 5 November 1927, FO37I/I2293/E4979/520/34. 
out very leniently for a number of years; men of military age, though called up yearly, would be allowed to buy exemption, and, as far as possible, only volunteers would be taken, and if conscripts were necessary they would be taken only from villages. The government was clearly attempting to defuse the opposition of specifically the better-off urban elements, particularly the guilds, without abandoning the central tenets of the conscription policy.

There was little chance of an agreement along these lines. The ulama, firmly established as the leadership of the movement, were motivated not just by dislike of conscription itself but by opposition to the general direction of the regime's reforms and by the steady diminishing of their own power. The opposition of the population in general to conscription was spontaneous, genuine and profound, and aggravated by the corruption of the recruiting commissions, while the more politically aware had wider grievances against the government, the most important being their resentment at the interference of the shah, the military and the government in the elections. Indeed the view was almost universally held that the Majlis then in session had been elected unconstitutionally. By the end of the first month the closure of the bazars in Shiraz and Isfahan and the strikes of the guilds were as solid as ever, and constant exhortations were being made to the ulama in other towns to join the movement. Although the big merchants were surreptitiously doing a certain amount of business, those of smaller substance were experiencing genuine distress while the severe hardship of the apprentices, petty shopkeepers and guildsmen was being alleviated by an arrangement giving them half-pay. ${ }^{28}$ The ulama themselves spent a considerable amount of money on sustaining the strike. Some, such as Ayatullah Isfahani himself, were very rich, and Isfahani was personally financing the movement in Isfahan.

Taymurtash's visit to Qum had produced no softening in the attitude of the bastis. The ulama in Qum had made no definite statement of their aims, but the situation was becoming increasingly complex, involving a multiplicity of grievances and demands. Although dislike of conscription had originally provoked the protest, there were many other objectives which the ulama now hoped to attain. They hated the new ministry of justice and they particularly disliked Taymurtash and his role at court. Most importantly they wanted the Constitution respected and the shah to be a constitutional monarch, leaving government to a fully responsible cabinet; they wanted the elections to be free and the deputies to be chosen by the people and not the appointees of the shah or the army; and, most crucial of all, they wanted implemented the constitutional provision for a supreme committee of five mujtahids able to scrutinize all bills introduced into the Majlis to ensure that nothing was done which contravened the shari'ah. So important to them was this last point that they argued that all laws passed by the 
Majlis in the absence of this committee were in fact unconstitutional and illegal. These opinions were a potent weapon. The ulama were apparently aiming especially at the legislation of the Fifth and Sixth Majlis, and specifically at the act which deposed the Qajar dynasty, thus threatening the legitimacy of the shah's newly established monarchy. ${ }^{29}$

Meanwhile the military authorities continued to make a show of implementing conscription. On I6 October the GOC in the south, General Mahmud Khan Ayrum, and the colonel in charge of conscription telegraphed from Isfahan to the press in Shiraz that 517 conscripts and 92 volunteers had been recruited, although the British consul-general in Isfahan noted in his diary that "some conscripts had presented themselves, but only those who had a valid excuse for not serving"30 while the appearance of volunteers had been secured by a judicious expenditure of money and the employment of old soldiers in civilian clothes. ${ }^{31}$ Finally, after several postponements, all liable for conscription in Isfahan were ordered to present themselves on 27 November. Of those called up, about 550 were exempted, about 300 presented themselves, and about 500 failed to answer the summons.

\section{A SETTLEMENT}

After the failure of Taymurtash's mission to Qum the shah realized that the situation was becoming dangerous. Despite the press censorship, news of the strike was being carried throughout the country and its duration began to convey an impression of powerlessness on the part of the central government, and of the decline of the control, civil and military, of the Pahlavi regime. At first the shah continued to insist that amendment of the conscription law rested with the Majlis, while the president of the Majlis, replying to the ulama of Shiraz, and the prime minister, replying to leaders of the merchants, repeated platitudes about leniency in taking conscripts. By early December the shah's impatience for a settlement became overwhelming. On Io December he sent the prime minister to Qum, accompanied by Taymurtash and two compliant Tehran clericals. They returned on the I4th, having arrived at an agreement with the ulama. The terms were not immediately announced but the next day the press printed copies of telegrams exchanged between the shah and the ulama. These telegrams were vague but complimentary and one from the ulama, in which the shah was referred to as the saviour of Iran, had obviously been composed under the influence of Taymurtash himself. This telegram, signed by Ayatullah Isfahani as well as Ayatullah Fishariki and two others, concluded with the hope that by the

29. Clive to Chamberlain, I9 November 1927, FO37I/I2293/E5207/520/34.

30. Quoted in Consul Chick, Shiraz, to Clive, I December 1927, FO371/13056/E40/40/34.

3I. IS no. 22, 29 October 1927. 
acts of the only saviour of Iran, Islam and the Muslims would enjoy happiness while the shah's reply stated that he never had any intention other than to safeguard the glory and greatness of Islam and to preserve all the respect and honour due to the spiritual leaders. ${ }^{32}$

A few days later two of the ulama from Qum came to Tehran, returning with the government's signature to the acceptance of the following five conditions: ${ }^{33}$

I A revision of the conscription law to be made by the next Majlis.

2 Five high-ranking mujtahids to form a committee to supervise the Majlis, as provided by the constitutional law.

3 Ecclesiastical supervisors for the provincial press to see that nothing antiIslamic is printed.

4 A strict veto on practices which are forbidden by Islam, such as drinking of wine, gambling, etc.

5 Reintroduction of the numerous small religious courts for dealing with personal status, the administration of oaths, etc., which had been newly centralized in the Central Court of Justice by the ministry of justice.

The government apparently also gave some verbal promises concerning other matters, including an undertaking that there would be no government interference in the next elections.

According to the press, these conditions were more or less those on which the truce had been made between Taymurtash and Isfahani; nonetheless the ulama who had returned from Tehran with the document bearing the government's signature received a very cold reception in Qum. The bastis had expected that their representatives would remain in the capital to see that the government put into immediate effect some at least of the conditions, while the fact that the modification of the conscription law had actually been postponed until the next Majlis was considered very unsatisfactory. It was at first uncertain what line the principal mujtahids gathered in Qum, especially Ayatullah Isfahani, by far the most influential and important, would ultimately adopt, but on 26 December Isfahani, a man of nearly 90 who had been unwell for some time, died. ${ }^{34}$ This deprived the anti-conscription movement of its leader and also weakened the influence of the remaining ulama over the population in general, making it likely that the truce would become a permanent settlement.

The people of Isfahan and Shiraz had by now become extremely battleweary and the onset of winter had further undermined both their resolve and that of the bastis in Qum while they were further demoralized by the

32. Translations in Consul Chick, Shiraz, to Clive, I December 1927.

33. Clive to Chamberlain, 29 December 1927, FO371/13056/E375/40/34.

34. Isfahani's death immediately gave rise to rumours that he had been poisoned on the orders of the Tehran authorities. Since he was aged and unwell, he may well have died of natural causes, although the shah's regime was certainly developing a habit of secretly murdering its opponents. 
death of Isfahani at a crucial moment in the negotiations. In fact the bazars in Isfahan had reopened on 4 December, even before the agreement was formally reached, while the strike ended in Shiraz on 27 December. The crisis was over and the general perception was of a government victory, little prestige having accrued to the ulama. It was true that the government had signed an agreement making certain concessions, but among the general population this was widely considered to be hardly worth the paper on which it was written.

Resistance to conscription was most organized and prolonged in the towns of the south, Isfahan and Shiraz, where leadership was provided by the ulama and the guilds. Elsewhere protests erupted in a more spontaneous way. On II December in Rasht, for example, serious anti-conscription riots broke out, led by the women of the town, and the bazars were closed. These riots resulted in twenty deaths, and martial law was proclaimed, a strict censorship imposed and an armoured car sent from the capital to overawe the population..$^{35}$

The government had already decided to exercise great leniency in the actual recruiting of conscripts and towards the end of 1927 continued at all only for appearance's sake. During December in the Tehran districts recruiting was carried out almost secretly and practically on a volunteer basis while when the commission declared its work complete in Kirmanshah town only 50 recruits had been taken. At the end of the year conscription, which had in any case very slackly been implemented in all the towns throughout the country, and only in the latter months extended to the districts, was temporarily cancelled altogether, and a few volunteers from villages were enlisted at practically the old volunteer rate of pay. From the very beginning the methods employed had allowed great leakage in manpower and the total number of recruits called up during 1927 probably did not exceed 3,000.

For the first six months of 1928 a certain leniency continued in the application of the law. Yet still wherever attempts were made to enforce the law, or even to carry out the registration, a degree of resistance was encountered. For instance early in January 1928 disturbances occurred in Maraghah, a town in Azarbayjan, in connection with compulsory registration of citizens for recruiting purposes while in Isfahan province a pro-conscription mulla was murdered by Bakhtiyari tribesmen. ${ }^{36}$ The work of the recruiting commissions proceeded haltingly and with difficulty, and they concentrated their efforts on the settled peasantry in the villages who were incapable of the organized, collective and sustained opposition shown by the better-off elements led by the guilds in the towns. During January and February a

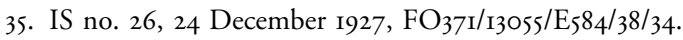

36. IS no. 2, 2I January I928, FO37I/I3055/E722/38/34; IS no. 4, I8 February 1928, FO37I/13055/

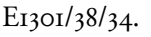


commission was active in Isfahan province, but no recruits were taken from Isfahan town, only from the villages. During April another attempt was made to apply the law in Isfahan itself but as a result of the outcry and the closing of the bazars it was again discontinued. Nonetheless the commission continued its activities in the surrounding villages, apparently collecting few men but a lot of money. ${ }^{37}$ By the end of April considerable hardship was being experienced in the villages around Hamadan although in the town the effect of conscription was practically nil. Again although by September there were about 800 conscripts undergoing their training in Rasht town, all were from the surrounding villages.

The work of the recruiting commissions was plagued by inefficiency, incompetence and corruption, paradoxically aggravated by the government's decision to implement the policy with leniency. In Rasht town the enrolling of recruits ceased on 7 February. The commission reported to Tehran that of I,I58 eligible men, I87 had been enlisted, 557 exempted, while the remainder had not presented themselves for examination. In Kurdistan, when the commission finished their task they had enlisted only about 60 recruits. In the Isfahan area only 40 per cent of those eligible for conscription had even been registered, but the chief conscription officer and his assistant were reported to be making a respectable fortune out of bribes. ${ }^{38}$

\section{NEW CONFLICTS}

Around the middle of 1928 the shah apparently decided the time had come to enforce conscription with renewed determination and he ordered his divisional commanders to make every effort towards making conscription a success. The ministry of the interior also ordered all provincial governors to give every assistance to the officials responsible for conscription and an energetic campaign was launched in both the national and local press in support of conscription as a patriotic duty. By mid-September it was clear that there was increased activity throughout the country in conscripting recruits. Nonetheless both the methods employed by the commissions and the results they obtained fell far short of the grandiose expectations of nationalist ideologues and they also continued to encounter constant opposition. In Kirmanshah, for example, recruiting was very busily carried on but it apparently took the form of seizing domestic servants who could later be "ransomed". ${ }^{9}$ In early October the bazars in Shiraz were again closed as a protest against the renewed call-up and there were some casualties as a result of a clash between the troops and demonstrators. In November in Kirman the methods used by the military authorities to obtain recruits

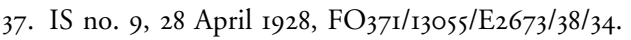

38. IS no. 6, I7 March 1928, FO371/13055/E2129/38/34.

39. IS no. I8, I September 1928, FO371/13055/E4673/38/34. 
caused widespread resentment and there was unrest in the city over both conscription and the enforcement of the new clothing reforms. ${ }^{40}$

However, in 1928 it was Tabriz, the provincial capital of Azarbayjan, which was the site of the major protest against conscription. Here, too, as with the previous year's protests, dislike of conscription enmeshed with wider resentment at the impact of the imposition of reform to produce an explosive situation and a general challenge to the tightening control of the Tehran regime.

By early 1928 nothing had yet been done to enforce conscription or even registration in Tabriz, a city with a reputation for political radicalism and general toughness. At the end of March the decision was made to enforce registration with drastic measures. For example, body washers and coffinmakers were to be obliged to demand proof of registration from families of deceased persons before providing their services. ${ }^{{ }^{\mathrm{I}}}$ Yet the authorities still met with little success and at the end of April, apprehensive at the depth of opposition, suspended the application of conscription to Azarbayjan.

The renewed determination of the authorities in the latter part of 1928 to impose conscription extended also to Tabriz where considerable unrest immediately manifested itself. Not only was there general and profound opposition to conscription but hostility to the government was greatly exaggerated by its decision to enforce simultaneously the wearing of the Pahlavi hat. The unrest thereby generated led to protest meetings being held in mosques and culminated in a demonstration by a crowd of about 10,000 on I7 October which was broken up by the police and the army with some violence. ${ }^{42}$ Arrests had begun even before the demonstration took place and continued for some time afterwards. A number of ulama were arrested and sent to Tehran, including one of the four mujtahids of Tabriz, Haj Mirza Abu'l Hasan Agha Angaji. Ayatullah Angaji had staunchly opposed the clothing reform and regarding conscription had advised the population, when faced with the dilemma of having to choose between submitting to the registration or abandoning their pilgrimages to Mecca, Karbala or Mashhad, to give up their pilgrimages. A number of rich merchants were also arrested. Besides having refused to attend a ceremony in honour of conscription to which they had been invited at the governor-general's palace, they were accused of having given money to the shopkeepers who had closed their shops, and of having provided tea and carpets for the various meetings. In fact some of these merchants had apparently only acted under considerable popular pressure. Less important people, such as anti-government

40. IS no. 2I, I3 October 1928, FO37I/I3055/E5275/38/34; IS no. 23, I7 November 1928, FO37I/ I3055/E5970/38/34. On 28 December the Majlis passed the Uniform Dress Law, which stated that the official clothing for Iranian men was the hat and suit and outlawed other forms of dress: see Chehabi, "Staging the Emperor's New Clothes".

4I. IS no. 7, 3I March 1928, FO371/13055/E2135/38/34.

42. Consul Gilliat-Smith, Tabriz, to Parr, I9 October 1928, FO371/13056/E521//40/34. 
mullas of the second rank, faced more serious consequences, being accused of inciting the people to resist the authorities and treason. Some of these were threatened with hanging, others were immediately flogged.

Through the end of 1928 and into 1929 the military authorities pressed on ruthlessly with conscription. In Tabriz many small shopkeepers, the element who had put up strongest resistance in the bazar, were recruited first. ${ }^{43}$ These men were often the mainstay of their families who were left on the verge of starvation. Rampant inefficiency and corruption prevailed everywhere. In Kirmanshah, for example, the dishonesty of the census officials was undisguised, more than one case having occurred in which bearded and wrinkled and obviously middle-aged men were written down as 2I, while in Isfahan a colonel of the Census Department who arrived on inspection duty brought to light several cases where bribes were taken for entering false ages. In Shiraz about Io per cent of those actually called up were Jews, a proportion far greater than their presence in the general population, and the Kirman conscription committee was reported to be taking every Zoroastrian they could lay their hands on. ${ }^{44}$ In Isfahan there were upwards of 60 per cent of absentees and elsewhere there were huge numbers of exemptions. In Gilan, of 550 names examined by the recruiting commission, only 66 were found liable for service. In Hamadan, of 300 conscripts called up, only 130 presented themselves, of whom nearly Ioo were exempted. Everywhere all those who were actually recruited were drawn from the very poorest sections of the population.

With the crushing of Tabriz, organized resistance to conscription in the towns of Iran was broken. The "religious-radical alliance", ${ }^{45}$ the cooperation between secular reformers and clerical dissidents, which had achieved such success during the constitutional revolution, was in I920s Iran no longer operative. Indeed this alliance had been sundered and the two elements put at loggerheads by the ascendancy of Riza Pahlavi and his launch of a modernizing state-building project. The ulama found themselves in opposition to the regime's agenda but without a coherent political and national alternative and were thus unable to provide sustained leadership to the anticonscription movement.

\section{RESISTANCE OF THE TRIBES}

Opposition to conscription then shifted to the rural areas. The peasantry was incapable of sustained and organized resistance, relying on escape by

43. Extract from Tabriz Consulate Diary, no. II, November I928, Clive to Chamberlain, I2 December 1928, FO37I/1378I/E95/95/34.

44. IS no. 2, I9 January I929, FO37I/I3784/EIo04/34; IS no. 23, I6 November 1929, FO37I/I3785/ E6248/104/34.

45. For an analysis of this concept see the pioneering work of Nikki Keddie, for example, "The Origins of the Religious-Radical Alliance in Iran”, in Nikki R. Keddie, Iran: Religion, Politics and Society (London, I980), pp. 53-65. 
flight or, where possessing the means, bribery. The tribes of Iran, however, were both politically more resourceful and more dangerous, still able to mobilize considerable armed strength. Although since I92I the government had been attempting, with varying degrees of success, to disarm the tribes and bring them under state control, the great tribal confederations of the south, the Bakhtiyari, the Qashqa'i and the Khamsah, and the Kurdish groupings of the west, were far from subdued.

There had never been any reluctance among the tribes to undertake military service. Irregular tribal levies, raised for specific campaigns and officered by tribal khans and chiefs, had indeed constituted the only significant military resource available to the Iranian state in the nineteenth century and still, in the late 1920s, continued to be of great importance to the fighting capacity of the army. Conscription, however, was viewed with horror. The absorption of large numbers of young men into a regular army, on the same terms as, and indistinguishable from, peasants and townsmen, their removal from the tribal environment and protection, their subordination to nontribal authority and the submergence of their tribal identity, was a process which struck at the foundations of tribal existence.

Opposition to conscription among the tribes was furthermore again embedded in a cluster of grievances and in 1929 a series of armed uprisings broke out in western and southern Iran. In Kurdistan the tribes, fearful of the extension of direct government control in general and in particular of the imposition of conscription and clothing reform, rose in January and drove the army out of the town of Sardasht and besieged the garrison in Saujbulak. Intermittent fighting continued until June, when the government concentrated troops in the Saujbulak area and drove the rebels back to their mountain homes, their leaders taking refuge across the Iraqi border. ${ }^{46}$

The rebellions in southern Iran, though motivated by much the same grievances, were more prolonged and serious. ${ }^{47}$ In the early summer of 1929 the Qashqa'i and then the Khamsah broke out into rebellion. Some of the smaller tribes joined in the movement and government authority was threatened throughout the province of Fars. At the beginning of June some sections of the Bakhtiyari in the province of Isfahan also revolted. Although the army had not yet attempted to call up tribesmen, fear of the future imposition of conscription was one of the principal causes of these uprisings. The tribes were also bitterly opposed to the new dress laws and to the regime's policy of disarmament and were exasperated after years of harsh treatment and extortion by the military officers placed over them by Riza Shah. ${ }^{48}$ The same core demands were put forward by all the rebellious tribes:

46. Consul Gilliat-Smith, Tabriz, to Clive, 6 June 1929, FO37I/1378I/E335I/95/34; Annual Report, I929, Clive to Henderson, 30 April I930, $\mathrm{FO}_{37 \mathrm{I}} / \mathrm{I} 4543 / \mathrm{E}_{2445} / 522 / 34$.

47. For these rebellions see Kavih Bayat, Shurish-i 'Asha'ir-i Fars (Tehran, I372); Ja'afar Quli Khan Amir-i Bahadur, Khatirat-i Sardar-i As'ad Bakhtiyari (Tehran, 1372), pp. 23I-232.

48. Annual Report, I929. 
they were not to be disarmed, and the conscription and dress laws were not to be applied to them. In addition each tribal group had specific grievances of its own. The Qashqa'i, for example, demanded the release from prison of their hereditary chief, Sawlat al-Dawlah, and his reinstatement as tribal ilkhani, while the Kurds had insisted that no Persian governor should be appointed in their areas. ${ }^{49}$

The government offered an amnesty to the Qashqa'i and restored Sawlat al-Dawlah, and also adopted a conciliatory approach to the Bakhtiyari, but it did not formally grant the demands of the tribesmen. The tribes' ability to offer a sustained challenge to the government was in any case weakened by their own lack of unity and by the end of the summer the tribal uprisings had subsided. Although no tribal conscripts were taken for the time being, the tribal uprisings, like the strikes and protests in Isfahan and Shiraz in 1927, had achieved little but a temporary and apparent concession. They had signally failed to arrest the overall centralizing drive of the regime or to alter the growing disparity between their own power and that of the state. Disarmament of the tribes and the consolidation of Tehran's control continued, to be followed inexorably as the 1930s progressed by conscription and ultimately forced settlement.

Nonetheless, throughout the I930s the regime exercised extreme caution when imposing conscription on the tribes, adopting a gradual, piecemeal approach. It was not until the mid-I93os that the first serious and systematic efforts were made to take recruits from the tribes, although from then on the reach of the recruiting commissions was slowly extended, year by year. By the late I930s, however, conscription had still not been universally applied to the tribes and was still provoking sporadic armed resistance..$^{\circ \circ}$

Although the shah had been prepared, when this was unavoidable, to temporize with the various elements of opposition, his ultimate determination to force conscription upon the population of Iran was never in doubt and he provided both the requisite political will and the necessary financial resources. In I93I and 1938 amendments aimed at generally strengthening the conscription law were passed by the Majlis and, organized resistance over, the way was clear for a massive expansion in the army's manpower. The shah initially stated that he wanted an army of 100,000 and indeed the army grew inexorably, from an estimated 37,000 in 1928 , to 87,000 in 1935 , reaching a massive 127,000 men organized in 18 divisions by 194I, thus actually exceeding the shah's original objectives.

However, although conscription certainly produced a large army, it did not produce a strong or efficient army. Despite the huge amounts of money spent annually on the army, the conscripts themselves endured extremely

49. Consul Gilliat-Smith, Tabriz, to Clive, 6 June I929; Annual Report, I929.

50. The rising of the Kurdish tribes in the Sardasht area in the spring of 1939, for example, was partly a result of the call for conscripts: IS no. 7, 8 April I939, FO371/2326I/E3024/216/34. 
harsh conditions. In 193I their pay was reduced from an already derisory 7 and a half qirans to 7 qirans per month (volunteers received 45 qirans per month). Their physique and stamina were reported to be unsatisfactory, they were worked hard in all weathers, badly fed and housed, and medical and sanitary arrangements were quite inadequate. ${ }^{\text {.I }}$ So bad was the situation that in 1931, on account of the high mortality amongst troops of the Tehran garrison, special medical officers were appointed by the shah himself as supervisors. The resulting low morale was compounded by a lack of proper training programmes and the atmosphere of arbitrary terror which the shah fostered within the army and which pervaded all ranks from the lowest to the highest. Such an army was naturally of little use on active service and throughout the I930s the military authorities continued to raise tribal levies for the small-scale operations which were its only occupation. ${ }^{52}$

Undoubtedly the harsh treatment to which the conscripts were subjected was made easier by the fact that the vast majority were drawn from the very poorest groups in Iranian society. Although the law had theoretically been tightened and occasionally scandals erupted resulting in the punishment of corrupt recruiting officers, nonetheless bribery and the purchase of exemptions were commonplace and nobody with a few spare tumans needed to "undergo the unpleasantness of the barrack square". .3 Indeed the regime appears to have decided, in the face of the 1927 episode, to use an almost institutionalized system of bribery to defuse the opposition of the better-off.

\section{CONCLUSION}

Conscription transformed the relationship between the army and Iranian society. Its introduction led to an unprecedented intrusion by the military into the lives of ordinary people and to their becoming enmeshed in the institutions of the modernizing state. It was an indispensable and key element in the regime's Persification campaign and in its drive to disseminate the official ideology of secular nationalism with a strong monarchical component. It furthermore provided, for the rural poor who made up the bulk of recruits, a dramatic introduction to modernity in general. Indeed the army, with its emphasis on uniformity, regularity, discipline, impersonal relationships and "measured time", may be seen as a quintessentially modern institution, preparing its peasant conscripts for the new demands of industrial capitalism.

Conscription also transformed the character of the Iranian army. It ended the traditional ethnic imbalance in Iranian military formations, the prepon-

5I. Annual Report, I93I, Hoare to Simon, I2 June 1932, FO371/16077/E3354/3354/34.

52. See, for example, Annual Report, 1936, Seymour to Eden, 30 January 1937, FO37I/20836/ EI435/I435/34.

53. Annual Report, 1930, Clive to Henderson, 22 May 1931, FO37I/15356/E3067/3067/34. 
derance of the Azari/Turkish element, and ultimately produced an officer corps and rank and file which more accurately reflected the ethnic composition of the country. In the short term, however, conscription destroyed what little military effectiveness the army had possessed. The fighting strength of the army had always resided in the tribal levies, their phasing out exposed the more or less complete inadequacy of the poorly-trained, badly-educated, harshly-treated conscripts. Fortunately for the regime the very pacification of the country which made the imposition of conscription possible, meant also an end to the tribal campaigning which had typified the I920s. The conscript army of the I930s was a parade-ground army, largely untried in battle and led by complacent and corrupt officers. Like other reforms of the Riza Shah period, conscription resulted in little more than a veneer of modernization. In I94I, when it met its first real test, the Iranian army disintegrated without a struggle, the conscripts simply sold their rifles to the tribes and went home, leaving the whole painful process of rebuilding the army to begin again from scratch. Indeed the mass desertions of 194I may perhaps be seen as the most spectacular example of popular resistance to conscription. 